\title{
An economic comparison of pasture-based production systems differing in sward type and cow genotype
}

\author{
B. McClearn, ${ }^{1,2} \odot$ L. Shalloo, ${ }^{1} \odot$ T. J. Gilliland, ${ }^{2} \odot$ F. Coughlan, ${ }^{1}$ and B. McCarthy ${ }^{1 *}$ \\ ${ }^{1}$ Teagasc, Animal and Grassland Research and Innovation Centre, Moorepark, Fermoy, Co. Cork, P61 C996, Ireland \\ ${ }^{2}$ Institute of Global Food Security, Queen's University Belfast, Belfast, BT9 5DL, Northern Ireland
}

\begin{abstract}
The objective of this study was to compare the economic performance of 2 sward types [perennial ryegrass (PRG; Lolium perenne L.) sown with or without white clover ( Trifolium repens L.)] grazed by 3 cow genotypes. Physical performance data were collected from a 4-yr systems experiment based at Clonakilty Agricultural College, Clonakilty, Co. Cork, Ireland. The experiment compared 2 sward types (PRG-only swards and PRG-white clover swards), with each sward type being grazed by cows from 3 genotypes [Holstein-Friesian $(\mathrm{HF})$, Jersey $\times$ HF $($ JEX), and Norwegian Red $\times$ JEX (3-way)]. All systems were stocked at 2.75 cows/ha with fixed fertilizer applications and concentrate supplementation. The data supplied 6 production systems ( 2 sward types $\times 3$ cow genotypes). The production systems were modeled using the Moorepark Dairy Systems Model (stochastic budgetary simulation model) under 2 scenarios, one in which land area was fixed and one in which cow numbers were fixed. The analysis was completed across a range of milk prices, calf prices, and reseeding programs. The analysis showed that in the fixed-land scenario with a milk price of $€ 0.29 / \mathrm{L}$, adding white clover to PRG swards increased profitability by $€ 305 /$ ha. In the same fixed-land scenario, JEX cows were most profitable $(€ 2,606 / \mathrm{ha})$, followed by 3 -way ( $€ 2,492 /$ ha) and HF (€2,468/ha) cows. In the fixed-cow scenario, net profit per cow was $€ 128$ greater for PRGwhite clover swards compared with PRG-only swards. In this scenario, JEX was the most profitable per cow (€877), followed by HF (€855) and 3-way (€831). The system that produced the highest net profit was JEX cows grazing PRG-white clover swards (€2,751/ha). Regardless of reseeding frequency or variations in calf value, JEX cows grazing PRG-white clover swards consistently produced the highest net profit per hectare.
\end{abstract}

Received September 6, 2019.

Accepted December 30, 2019

*Corresponding author: brian.mccarthy@teagasc.ie
Key words: white clover, crossbreeding, spring calving

\section{INTRODUCTION}

With the recent abolition of milk quotas in the European Union, there has been a large increase in milk production in Ireland driven by an increase in cow numbers and milk yield per cow (Läpple and Sirr, 2019). Dairy production systems in Ireland are primarily pasture based, and factors such as soil type (Shalloo et al., 2004a), stocking rate (Macdonald et al., 2008), grazing season length (Läpple et al., 2012), and supplemental feed use (Ramsbottom et al., 2015: Macdonald et al., 2017; Hanrahan et al., 2018) can affect the efficiency and profitability of these systems. However, it is acknowledged that pasture use (Ramsbottom et al., 2015; Hanrahan et al., 2018) and cow genotype (McCarthy et al., 2007; Prendiville et al., 2011b) are 2 of the main factors that affect profitability within pasture-based dairy production systems.

Perennial ryegrass (Lolium perenne L.; PRG) is the main grass species grown in temperate regions of the world and is the cheapest feed available for dairy cows (McGilloway, 2005; Finneran et al., 2012). However, there has been renewed interest in including forage legumes, particularly white clover (Trifolium repens L.), in PRG swards due to its ability to biologically fix nitrogen $(\mathrm{N})$ and reduce inorganic $\mathrm{N}$ fertilizer use while maintaining or increasing pasture DM production and pasture nutritive value (Lüscher et al., 2014; Delaby et al., 2016). Enriquez-Hidalgo et al. (2014) and Guy et al. (2018) reported increased pasture production and utilization with PRG-white clover swards compared with PRG-only swards at similar $\mathrm{N}$ fertilizer rates. Recent research has also re-emphasized the beneficial effects of white clover inclusion in PRG swards on animal performance, as dairy cows grazing PRG-white clover swards can have higher milk yields compared with cows grazing PRG-only swards (Egan et al., 2018; McClearn et al., 2019). Schils et al. (2000) reported that gross margin was higher per farm and per cow (although not per hectare) on PRG-white clover swards fertilized 
with low N compared with PRG-only swards fertilized with higher N. In contrast, Humphreys et al. (2012) reported similar net margin per hectare for PRG-only swards receiving high levels of artificial $\mathrm{N}$ compared with PRG-white clover swards receiving reduced $\mathrm{N}$ fertilizer annually. However, the systems used in these studies are not directly comparable because the PRGwhite clover swards did not receive the same $\mathrm{N}$ fertilizer input levels as the PRG-only swards.

As stated previously, cow genotype can have a significant effect on the profitability of pasture-based production systems due to differences in milk and milk solids (MSo; $\mathrm{kg}$ of fat + protein) yield, reproductive performance, and functional traits (McCarthy et al., 2007). The use of crossbreeding to exploit favorable characteristics of "alternative" genotypes can remove the negative effects associated with inbreeding and capitalize on heterosis. Crossbreeding has generated increased interest in the last 2 decades (Buckley et al., 2014). Several studies have reported improved animal performance in terms of both MSo production and reproductive performance (Prendiville et al., 2011a; Vance et al., 2013; Coffey et al., 2017) and economic performance (Lopez-Villalobos et al., 2000, Prendiville et al., 2011b) for Jersey $\times$ Holstein-Friesian $($ HF) crossbred cows compared with their purebred parent genotypes in pasture-based production systems. Although Jersey $\times$ HF $(\mathbf{J E X})$ is the most common crossbred found in pasture-based systems, crossbreds of Norwegian Red, Montbéliarde, and Normande with HF have been shown to have superior reproductive performance with similar or increased MSo production per cow compared with HF (Heins et al., 2006; Walsh et al., 2007; Buckley et al., 2014). The improved reproductive performance, higher survivability, and increased MSo yield per cow due to a greater proportion of mature crossbred cows surviving in the herd generally make them suitable for spring-calving, pasture-based systems (Buckley et al., 2014).

To fully evaluate the economic impact of variations in animal performance and production as a consequence of changes in sward type and cow genotype, a multidisciplinary systems simulation approach was required. This simulation included the effects of all major farm components, including all production revenues as well as combining variable and fixed costs. The objective of this study was to investigate the profitability of springcalving grazing dairy production systems differing in sward type (PRG only or PRG-white clover) and dairy cow genotype [HF, JEX, and Norwegian Red $\times$ JEX (3-way)] under differing scenarios in which land area was fixed (reflective of the situation on most Irish farms) and cow numbers were fixed (which could be reflective of potential future restrictions at farm level). The analysis was completed across a range of milk and calf prices and reseeding programs.

\section{MATERIALS AND METHODS}

\section{Production Study Details}

The design of the 4-yr study along with the production and reproduction data used in the analysis of the 2 sward types and 3 genotypes were previously reported by McClearn et al. (2019). As described by McClearn et al. (2019), 4 sward types were evaluated: a tetraploid PRG-only sward, a diploid PRG-only sward, a tetraploid PRG sward with white clover, and a diploid PRG sward with white clover. Sward white clover content was $23 \%$ on average over the 4 -yr period for the tetraploid PRG with white clover and the diploid PRG with white clover swards. As there was no difference in pasture or milk production between tetraploid and diploid swards, this economic analysis used an average of the tetraploid and diploid PRG-only swards for the PRG-only values. Likewise, an average of the tetraploid and diploid PRG swards with white clover was used for the PRG-white clover values. Each grazing treatment was stocked at 2.75 cows/ha and comprised 10.9 ha divided into 20 paddocks that were balanced for location block, soil type, and soil fertility throughout the farm and received $250 \mathrm{~kg}$ of $\mathrm{N} /$ ha per year.

Three cow genotypes were evaluated: HF, JEX, and 3 -way. The HF genotype was chosen to represent the predominant breed group used in Ireland. The JEX genotype was used to represent the most common firstgeneration $\left(\mathbf{F}_{\mathbf{1}}\right)$ crossbred used in pasture-based dairy systems, and the 3-way genotype was used to compare a 3-way rotational crossbred animal with the original $\mathrm{F}_{1}$ JEX. The JEX cows were produced from HF cows mated with a Jersey sire to produce an $F_{1}$ crossbred animal. The 3 -way cows were produced from $\mathrm{F}_{1}$ JEX cows mated with a Norwegian Red sire. Every year, 20 cows of each genotype were assigned to each of the 2 sward types and balanced for parity $(1,2$, or $3+)$, calving date, and economic breeding index (EBI), giving a total of 40 cows of each genotype in the experiment each year. Age structure did not differ among genotype for the duration of the experiment. Consequently, a total of 472 lactations from 242 spring-calving dairy cows were used $(35,24,24$, and 24 primiparous and 81, 93, 95, and 96 multiparous in 2014, 2015, 2016, and 2017 , respectively). The parental average EBI is shown in Table 1 for all 3 genotypes. The parental average EBI reported was updated in January 2019 (http:// www.icbf.com) and is presented instead of actual cow 
Table 1. Mean economic breeding index (EBI), subindices, and PTA for each cow genotype ${ }^{1}$

\begin{tabular}{lccc}
\hline Item & HF & JEX & 3-Way \\
\hline EBI $^{2}$ & 115 & 131 & 159 \\
Subindices & & & \\
Milk & 38.7 & 52.1 & 43.4 \\
Fertility & 42.1 & 30.7 & 62.5 \\
Health & 1.5 & 0.7 & 4.0 \\
Calving & 31.6 & 33.6 & 37.2 \\
Beef & -8.9 & -27.6 & -16.7 \\
Maintenance & 8.5 & 36.5 & 25.9 \\
Management & 1.2 & 4.8 & 2.4 \\
PTA & & & \\
Milk (kg) & 44.0 & -87.1 & -76.0 \\
Fat (kg) & 6.8 & 10.5 & 7.8 \\
Protein (kg) & 4.9 & 3.8 & 3.5 \\
Fat (\%) & 0.08 & 0.24 & 0.19 \\
Protein (\%) & 0.06 & 0.12 & 0.11 \\
\hline
\end{tabular}

${ }^{1} \mathrm{HF}=$ Holstein-Friesian; JEX $=$ Jersey $\times$ Holstein-Friesian; 3-way $=$ Norwegian Red $\times$ (Jersey $\times$ Holstein-Friesian $)$.

${ }^{2}$ The EBI for each cow was calculated from its parental average EBI taken from the January 2019 Irish Cattle Breeding Federation (http:/ /www.icbf.com) evaluation run.

values to exclude the effect of grazing treatment on individual cow performance. The overall EBI differed between genotypes, with HF at €115, JEX at €131, and 3 -way at $€ 159$. Cows were bred to bulls with a calving difficulty of less than $5 \%$ for mature cows and less than $2.5 \%$ for heifers. Over the 4 -yr study, the 3 genotypes were mated to a total of 40 bulls, of which 22 were HF, 8 were Jersey, 7 were Norwegian Red, and 3 were beef breeds. Beef sires were used on cows that were considered unsuitable for breeding replacements due to production or health issues. Each year during the study, $50 \%$ of HF cows were inseminated with $\mathrm{HF}$ straws and $50 \%$ were inseminated with Jersey straws to produce $\mathrm{HF}$ and $\mathrm{F}_{1} \mathrm{JEX}$ replacements. All JEX $\mathrm{F}_{1}$ cows were inseminated with Norwegian Red straws, and all 3 -way cows received HF straws. All sires used in the experiment had an EBI value and were commercially available in Ireland (with Jersey and Norwegian Red sires typically imported by Irish AI companies from New Zealand and the Scandinavian countries, respectively). The sires used were in the top $10 \%$ of their breed on the EBI each year.

Milk production, BW, and BCS from the 4-yr study are shown in Table 2 and were used for the economic modeling (McClearn et al., 2019). Reproductive performance is not presented because it did not differ significantly between sward type or cow genotype. Therefore, an average reproductive performance for all groups was used for the economic analysis. Average 6-wk pregnancy rate was $87 \%$ and overall 12 -wk pregnancy rate was $94 \%$ for all 3 genotypes.

\section{Economic Analysis}

The Moorepark Dairy Systems Model (MDSM; Shalloo et al., 2004b), a stochastic budgetary simulation model, was used to simulate a model farm using the biological data for each sward type and each cow genotype. The model integrates animal inventory and valuation, milk production, pasture production, feed requirements, land and labor used, and an economic analysis. Land area was treated as an opportunity cost, with additional land rented when required and leased out when not required for on-farm feeding of animals. Variable costs (fertilizer, contractor charges, veterinary fees, AI, and feed costs) and fixed costs (machinery running and maintenance, farm maintenance, car, telephone, electricity, and insurance) were based on current prices (Teagasc, 2013). The feeds offered (pasture, pasture silage, and concentrate) were determined by the MDSM meeting the net energy requirement for milk production and BW change (Jarrige, 1989). Table 3 shows the key assumptions used in the model for the 6

Table 2. The effect of sward type $e^{1}$ and cow genotype ${ }^{2}$ on milk production, BW, BCS, silage fed, and labor per cow

\begin{tabular}{|c|c|c|c|c|c|c|}
\hline \multirow[b]{2}{*}{ Item } & \multicolumn{3}{|c|}{ PRG only } & \multicolumn{3}{|c|}{ PRG-white clover } \\
\hline & $\mathrm{HF}$ & JEX & 3-Way & $\mathrm{HF}$ & JEX & 3-Way \\
\hline Lactation length (d) & 282 & 285 & 279 & 283 & 285 & 280 \\
\hline Milk yield (kg/cow) & 5,365 & 5,181 & 5,119 & 6,072 & 5,771 & 5,609 \\
\hline Fat content $(\%)$ & 4.58 & 4.87 & 4.73 & 4.47 & 4.86 & 4.78 \\
\hline Protein content (\%) & 3.75 & 3.91 & 3.89 & 3.69 & 3.83 & 3.87 \\
\hline Milk solids yield ${ }^{3}$ (kg/cow) & 447 & 455 & 441 & 495 & 501 & 485 \\
\hline $\mathrm{BW}(\mathrm{kg})$ & 527 & 476 & 496 & 533 & 480 & 502 \\
\hline $\mathrm{BCS}$ & 2.92 & 2.93 & 3.00 & 2.94 & 2.96 & 2.98 \\
\hline Silage fed (kg of DM/cow per year) & 363 & 363 & 363 & 441 & 441 & 441 \\
\hline Labor $(\mathrm{h} / \mathrm{cow})$ & 30 & 30 & 30 & 31.2 & 31.2 & 31.2 \\
\hline
\end{tabular}

${ }^{1} \mathrm{PRG}=$ perennial ryegrass.

${ }^{2} \mathrm{HF}=$ Holstein-Friesian; JEX $=$ Jersey $\times$ Holstein-Friesian; 3 -way $=$ Norwegian Red $\times($ Jersey $\times$ Holstein-Friesian $)$.

${ }^{3}$ Milk solids $=\mathrm{kg}$ of fat + protein. 
treatments simulated. In all simulations, all calves were sold at 1 mo of age. All male calves were assumed sold for market value, with a value of $€ 53$, €34, and $€ 20$ for HF, 3-way, and JEX, respectively, and with all female calves included in the model at $€ 350$ each. These calf value assumptions were based on actual market values recorded throughout the study. Replacement females were bought for $€ 1,545$ based on rearing costs (Shalloo et al., 2014) and were brought onto the farm 1 mo before calving. Cull cow values were generated based on the assumption that cows were culled directly from the milking parlor. The 3 -way and HF cows were assumed to have a killout percentage of $42 \%$ and a market carcass value of $€ 1.50 / \mathrm{kg}$, whereas the JEX cows were assumed to have a killout of $40 \%$ and a market carcass value of $€ 1.25 / \mathrm{kg}$ (Prendiville at al., 2011b). Labor costs were calculated based on a labor requirement of $30 \mathrm{~h} /$ cow per year, where $1,848 \mathrm{~h}$ was considered equal to 1 labor unit/yr, at a cost of $€ 22,855$.

As a result of white clover being in the sward, there is less pasture growth over winter and subsequently lower pasture availability in spring (Guy et al., 2018). Therefore, within the systems simulated there was a requirement for additional silage supplementation in spring for cows on PRG-white clover swards. This was included as a labor and machinery cost across the PRG-white clover treatments. The requirement for bloat oil and the infrastructure and management time to administer it were also included in the PRG-white clover treatments.

\section{Scenarios}

With the removal of the European Union milk quota system, the main limiting factors within pasture-based dairy production systems center on land area, but in the future there could be cow number restrictions depending on environmental policy. Therefore, the analysis was completed with both land area and cow number restrictions included. The herds were compared across

Table 3. Herd default assumptions used in the Moorepark Dairy Systems Model

\begin{tabular}{lc}
\hline Variable & Value \\
\hline Farm size (ha) & 40 \\
Concentrate cost $(€ / \mathrm{t})$ & 280 \\
Opportunity cost of land $(€ /$ ha) & 450 \\
Housing cost $(€ /$ cow) & 1,617 \\
Replacement heifer cost $(€ /$ animal $)$ & 1,545 \\
Labor cost $(€ / \mathrm{h})$ & 12.40 \\
Fertilizer cost, urea $(€ / \mathrm{t})$ & 420 \\
Fertilizer cost, calcium ammonium nitrate $(€ / \mathrm{t})$ & 320 \\
Milk price ratio, protein:fat & 1.5 \\
\hline
\end{tabular}

3 future base milk prices of $€ 0.24$, €0.29, and $€ 0.34 / \mathrm{L}$, assuming reference milk contents of $33.0 \mathrm{~g} / \mathrm{kg}$ of protein and $36.0 \mathrm{~g} / \mathrm{kg}$ of fat and a relative milk price ratio of 1:1.5 for fat:protein within a multiple-component (A $+\mathrm{B}-\mathrm{C}$ ) milk payment pricing regimen (Geary et al., 2010). Sensitivity around calf prices was included where calf value differences between the HF cows and the JEX and 3-way cows were increased by $€ 30$ and $€ 60$ per calf, respectively, across the board. Finally, the simulations were completed where the reseeding frequency was increased from every $10 \mathrm{yr}$ for PRG-only swards to every 5 yr for PRG-white clover swards.

\section{RESULTS}

\section{Influence of Sward Type and Cow Genotype on Farm Profitability}

Table 4 shows the effect of sward type on farm profitability in a scenario in which land is limited to 40 ha and milk price is $€ 0.29 / \mathrm{L}$. Stocking rate varies for sward type as the MDSM determines the net energy requirement based on milk produced and BW changes. The PRG-white clover swards are stocked lower than PRG-only swards due to their higher milk yield per cow (average of $+594 \mathrm{~kg}$ ), and therefore there is a higher net energy requirement even though more pasture is used per hectare $(+1,080 \mathrm{~kg}$ of DM/ha). On average, the PRG-only 40-ha farm supported 119 cows, whereas the PRG-white clover supported 116 cows. On average across all 3 genotypes, MSo output was $105 \mathrm{~kg} /$ ha greater on PRG-white clover swards than on PRGonly swards. Across all 3 genotypes, costs were $€ 129 /$ ha higher on PRG-white clover swards due to higher silage and labor requirements and additional costs associated with the inclusion of bloat oil. However, profitability was €305/ha higher with PRG-white clover swards compared with PRG-only swards (€2,369 vs. €2,674 for PRG-only and PRG-white clover swards, respectively).

Table 4 also shows the effect of cow genotype on farm profitability. Stocking rate varies for cow genotype based on energy requirements. On average over the 2 sward types, $116 \mathrm{HF}, 119$ JEX, and 119 3-way cows were stocked on a 40-ha farm. Milk output averaged $1,326 \mathrm{~kg} / \mathrm{ha}$ for HF cows, $1,382 \mathrm{~kg} / \mathrm{ha}$ for JEX cows, and $1,346 \mathrm{~kg} / \mathrm{ha}$ for 3 -way cows. Costs were higher for JEX and 3-way than for HF due to the additional cows on farm; however, profitability was highest for JEX $(€ 2,606 /$ ha) cows, followed by 3 -way $(€ 2,492 /$ ha) and HF $(€ 2,468)$ cows. The highest net profit per farm was achieved with JEX cows on PRG-white clover swards (€110,037/farm or $€ 2,751 /$ ha) at a stocking rate of 2.93 cows/ha (117 cows on 40 ha). The lowest net profit per farm was achieved with HF cows on PRG-only swards 
Table 4. The effect of sward type ${ }^{1}$ and cow genotype ${ }^{2}$ in a fixed land area (40 ha) with a milk price of $€ 0.29 / \mathrm{L}$

\begin{tabular}{|c|c|c|c|c|c|c|}
\hline Item & \multicolumn{3}{|c|}{ PRG only } & \multicolumn{3}{|c|}{ PRG-white clover } \\
\hline Cows (no.) & 117 & 120 & 120 & 114 & 117 & 118 \\
\hline Grass used ( $\mathrm{kg}$ of DM/ha) & 13,896 & 13,896 & 13,896 & 14,976 & 14,976 & 14,976 \\
\hline Milk produced (kg) & 625,522 & 620,122 & 614,772 & 690,126 & 674,291 & 660,978 \\
\hline Milk solids ${ }^{3}$ output $(\mathrm{kg})$ & 50,875 & 53,204 & 51,766 & 55,199 & 57,369 & 55,933 \\
\hline Costs $(€)$ & 159,722 & 162,224 & 162,719 & 164,201 & 167,391 & 168,513 \\
\hline Net profitability $(€)$ & 92,136 & 98,423 & 93,764 & 105,276 & 110,037 & 105,578 \\
\hline Net profitability per cow $(€)$ & 787 & 822 & 781 & 926 & 942 & 896 \\
\hline Net profitability per hectare $(€)$ & 2,303 & 2,461 & 2,344 & 2,632 & 2,751 & 2,639 \\
\hline Net profitability per kilogram of milk solids $(€)$ & 1.81 & 1.85 & 1.81 & 1.91 & 1.92 & 1.89 \\
\hline
\end{tabular}

${ }^{1} \mathrm{PRG}=$ perennial ryegrass.

${ }^{2} \mathrm{HF}=$ Holstein-Friesian; JEX $=$ Jersey $\times$ Holstein-Friesian; 3-way $=$ Norwegian Red $\times($ Jersey $\times$ Holstein-Friesian $)$.

${ }^{3}$ Milk solids $=\mathrm{kg}$ of fat + protein.

(€92,136/farm or $€ 2,303 /$ ha) with 117 cows on 40 ha. As a result, the difference in net profit between the highest and lowest treatments was $€ 17,00 /$ farm, €448/ ha, and $€ 155 /$ cow.

\section{Fixed Cow Numbers}

Table 5 shows the key herd output variables from the MDSM for the 2 sward types and 3 genotypes when cow numbers are fixed to 114 and land used is variable with a base milk price of $€ 0.29 / \mathrm{L}$. In this scenario, land use varies with sward type and cow genotype due to herd demand. There was a lower land requirement for PRG-only swards compared with PRG-white clover swards; however, this did not make them more profitable because the higher output from the PRG-white clover swards (milk + pasture) offset the requirement for more land area. Net farm profitability for PRGwhite clover swards was $€ 14,572$ higher than PRG-only swards for 114 cows, €364 higher per hectare, and €128 higher per cow. Net farm profitability was highest for JEX cows $(€ 99,571)$ compared with HF $(€ 97,114)$ and 3 -way (€94,504) cows. This is also reflected in profitability per hectare, with JEX being the most profitable $(€ 2,489)$, followed by HF $(€ 2,428)$ and 3 -way $(€ 2,363)$. In this scenario, the 3 -way cows are the least profitable due to their lower MSo production compared with HF and JEX. The highest net profit ( $€ 106,563 /$ farm, $€ 2,664 /$ ha, and $€ 938 /$ cow) was achieved from JEX cows grazing PRG-white clover swards due to a combination of higher milk output from PRG-white clover swards and higher milk value from JEX cows.

Table 5. The effect of sward type ${ }^{1}$ and cow genotype ${ }^{2}$ in a scenario with fixed cow numbers at a milk price of $€ 0.29 / \mathrm{L}$

\begin{tabular}{|c|c|c|c|c|c|c|}
\hline \multirow[b]{2}{*}{ Item } & \multicolumn{3}{|c|}{ PRG only } & \multicolumn{3}{|c|}{ PRG-white clover } \\
\hline & $\mathrm{HF}$ & JEX & 3-Way & $\mathrm{HF}$ & JEX & 3-Way \\
\hline Cows (no.) & 114 & 114 & 114 & 114 & 114 & 114 \\
\hline Hectares & 39 & 38 & 38 & 40 & 39 & 39 \\
\hline Grass used (kg of DM/ha) & 13,896 & 13,896 & 13,896 & 14,976 & 14,976 & 14,976 \\
\hline Milk produced $(\mathrm{kg})$ & 607,349 & 588,857 & 581,811 & 690,126 & 655,915 & 637,502 \\
\hline Milk solids ${ }^{3}$ output (kg) & 49,397 & 50,522 & 48,990 & 55,199 & 55,806 & 53,946 \\
\hline Labor $(€)$ & 42,179 & 42,179 & 42,179 & 43,641 & 43,641 & 43,641 \\
\hline Gross output (€) & 244,100 & 247,052 & 242,300 & 268,903 & 269,295 & 263,811 \\
\hline Costs $(€)$ & 155,587 & 154,922 & 154,927 & 164,201 & 163,302 & 163,144 \\
\hline Net profitability $(€)$ & 88,952 & 92,580 & 87,799 & 105,276 & 106,563 & 101,209 \\
\hline Net profitability per cow $(€)$ & 783 & 815 & 772 & 926 & 938 & 890 \\
\hline Net profitability per hectare $(€)$ & 2,224 & 2,314 & 2,195 & 2,632 & 2,664 & 2,530 \\
\hline Net profitability per kilogram of milk solids $(€)$ & 1.80 & 1.83 & 1.79 & 1.91 & 1.91 & 1.88 \\
\hline
\end{tabular}

${ }^{1} \mathrm{PRG}=$ perennial ryegrass.

${ }^{2} \mathrm{HF}=$ Holstein-Friesian; JEX $=$ Jersey $\times$ Holstein-Friesian; 3 -way $=$ Norwegian Red $\times($ Jersey $\times$ Holstein-Friesian $)$.

${ }^{3}$ Milk solids $=\mathrm{kg}$ of fat + protein. 
Table 6. The effect of sward type ${ }^{1}$ and cow genotype ${ }^{2}$ in a fixed land area (40 ha) with varying milk price (€0.24 or $\left.€ 0.34 / \mathrm{L}\right)$

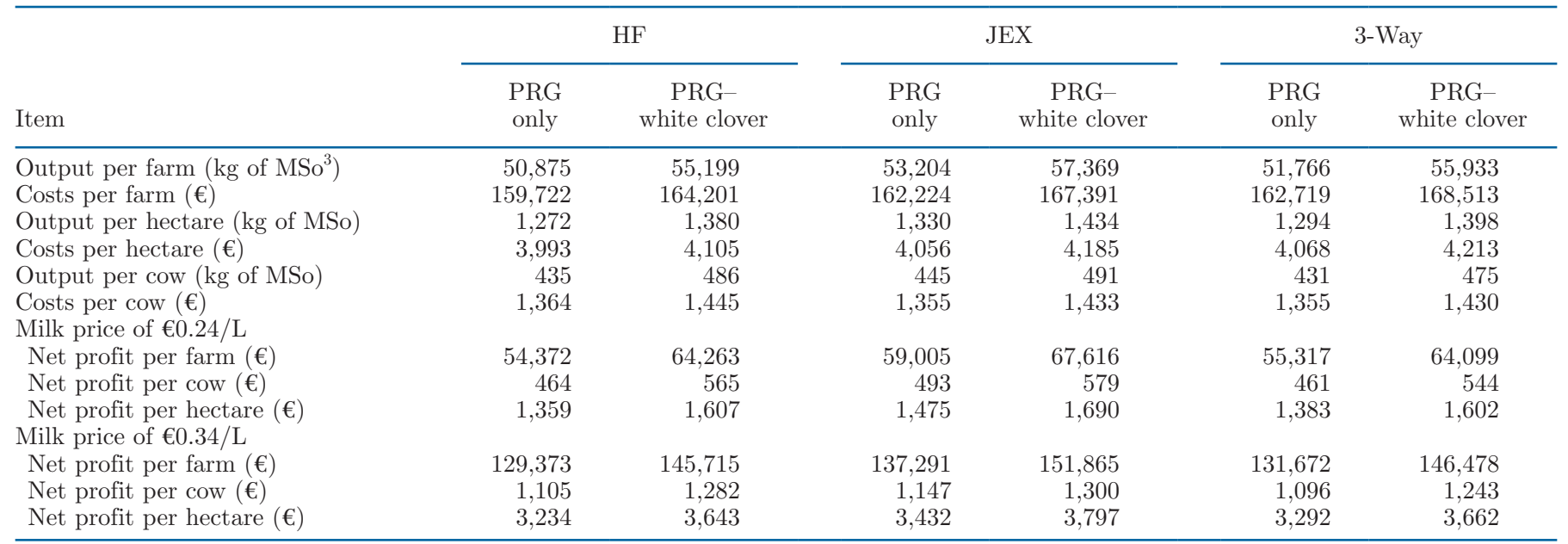

${ }^{1} \mathrm{PRG}=$ perennial ryegrass.

${ }^{2} \mathrm{HF}=$ Holstein-Friesian; JEX $=$ Jersey $\times$ Holstein-Friesian; 3 -way $=$ Norwegian Red $\times($ Jersey $\times$ Holstein-Friesian $)$.

${ }^{3} \mathrm{MSo}=$ milk solids $(\mathrm{kg}$ of fat + protein).

\section{Sensitivity Analysis}

Table 6 shows the changes in profitability when milk price varies by $€ 0.05 / \mathrm{L}$ above and below the base milk price of $€ 0.29 / \mathrm{L}$ (i.e., $€ 0.24$ and $€ 0.34 / \mathrm{L}$ ). The trend for PRG-white clover swards to be more profitable than PRG-only swards carried through for each milk price scenario (Table 6 ). At $€ 0.24 / \mathrm{L}$, the PRG-white clover swards were still more profitable than PRG-only swards (€1,633 vs. €1,406/ha). At €0.34/L, the PRGwhite clover swards were $+€ 15,241 /$ farm, +€381/ ha, and $+€ 159 /$ cow more profitable than PRG-only swards. At $€ 0.24 / \mathrm{L}$, JEX cows were most profitable (€1,583/ha), followed by 3 -way cows $(€ 1,493 /$ ha) and HF cows $(€ 1,483 /$ ha). Similarly, this trend carried over when milk price was $€ 0.34 / \mathrm{L}$, with JEX being the most profitable (€3,614/ha), followed by 3-way (€3,477/ha) and HF ( $€ 3,439 /$ ha). At $€ 0.24 / \mathrm{L}$, there was a net profit difference of $€ 13,244 /$ farm, $€ 331 /$ ha, and $€ 144 /$ cow be- tween JEX cows on PRG-white clover swards and HF cows on PRG-only swards. At $€ 0.34 / \mathrm{L}$, the difference increased linearly with an additional profit of $€ 22,491 /$ farm, €562/ha, and €195/cow.

Table 7 shows the key herd output variables from the MDSM for the 2 sward types, again in the fixed-land scenario but in this case when reseeding is increased to every 5 yr for PRG-white clover swards compared with every $10 \mathrm{yr}$ for PRG-only swards. Increasing reseeding frequency to every $5 \mathrm{yr}$ for $\mathrm{PRG}$-white clover swards increased average costs by $€ 7,246 /$ farm (€181/ha) compared with PRG-only swards reseeded every $10 \mathrm{yr}$. However, net profit was still considerably higher from PRG-white clover swards compared with PRG-only swards, despite the increased reseeding cost $(+€ 10,089$ / farm and $+€ 252 /$ ha).

Table 8 shows the key herd output variables from the MDSM for the 3 cow genotypes in the fixed-land scenario with a milk base price of $€ 0.29 / \mathrm{L}$ when calf value

Table 7. The effect of sward type ${ }^{1}$ and cow genotype ${ }^{2}$ in a fixed land area (40 ha) with a milk price of $€ 0.29 / \mathrm{L}$ and an increased reseeding frequency of every $5 \mathrm{yr}$ for PRG-white clover swards versus every $10 \mathrm{yr}$ for PRG-only swards

\begin{tabular}{|c|c|c|c|c|c|c|}
\hline Item & \multicolumn{2}{|c|}{$\mathrm{HF}$} & \multicolumn{2}{|c|}{ JEX } & \multicolumn{2}{|c|}{ 3-Way } \\
\hline Costs $(€)$ & 159,722 & 166,301 & 162,224 & 169,491 & 162,719 & 170,613 \\
\hline Net profit per farm $(€)$ & 92,136 & 103,176 & 98,423 & 107.937 & 93,764 & 103,478 \\
\hline Net profit per cow $(€)$ & 787 & 908 & 822 & 924 & 781 & 878 \\
\hline
\end{tabular}

${ }^{1} \mathrm{PRG}=$ perennial ryegrass.

${ }^{2} \mathrm{HF}=$ Holstein-Friesian; JEX $=$ Jersey $\times$ Holstein-Friesian; 3 -way $=$ Norwegian Red $\times($ Jersey $\times$ Holstein-Friesian $)$.

${ }^{3}$ Milk solids $=\mathrm{kg}$ of fat + protein. 
Table 8. The effect of sward type ${ }^{1}$ and cow genotype ${ }^{2}$ in a fixed land area (40 ha) with a milk price of $€ 0.29 / \mathrm{L}$ and varying calf sale values (increase calf price by $€ 30$ or $€ 60$ for HF and 3-way compared with JEX)

\begin{tabular}{|c|c|c|c|c|c|c|}
\hline Item & \multicolumn{2}{|c|}{$\mathrm{HF}$} & \multicolumn{2}{|c|}{ JEX } & \multicolumn{2}{|c|}{ 3-Way } \\
\hline Net profit per farm $(€)$ & 94,122 & 107,204 & 98,423 & 110,037 & 95,801 & 107,578 \\
\hline Net profit per cow $(€)$ & 804 & 943 & 822 & 942 & 798 & 913 \\
\hline Net profit per hectare $(€)$ & 2,353 & 2,680 & 2,461 & 2,751 & 2,395 & 2,689 \\
\hline Net profit per cow $(€)$ & 821 & 960 & 822 & 942 & 815 & 930 \\
\hline Net profit per hectare $(€)$ & 2,403 & 2,728 & 2,461 & 2,751 & 2,446 & 2,739 \\
\hline
\end{tabular}

${ }^{1} \mathrm{PRG}=$ perennial ryegrass.

${ }^{2} \mathrm{HF}=$ Holstein-Friesian; JEX $=$ Jersey $\times$ Holstein-Friesian; 3 -way $=$ Norwegian Red $\times($ Jersey $\times$ Holstein-Friesian $)$.

${ }^{3}$ Increase in calf price of $\mathrm{HF}$ and 3-way compared to JEX.

varies. In this scenario, $\mathrm{HF}$ and 3-way male calf values are modeled with the original prices included (€53, €34, and $€ 20$ for HF, 3-way, and JEX, respectively); and in addition, the value of the $\mathrm{HF}$ and 3-way male calves increased by $€ 30$ and $€ 60$, respectively, compared with JEX calves. The effect of the higher value male calves from $\mathrm{HF}$ and 3-way cows results in the profit of the HF group increasing by $€ 1,957 /$ farm and $€ 49 /$ ha and the profit of the 3-way cow increasing by $€ 2,018 /$ farm and $€ 50 /$ ha for the scenario with the increase in the differential of $€ 30$. The corresponding figures for the increase in calf price differential of $€ 60$ are $€ 3,915 /$ farm and $€ 98 /$ ha for HF cows and $€ 4,037 /$ farm and $€ 101 /$ ha for 3 -way cows. Even at an increase in calf price differential of $€ 60$, the JEX animals are still most profitable on a per-hectare basis (€2,606 compared with $€ 2,566$ and $€ 2,593$ for $\mathrm{HF}$ and 3-way, respectively).

\section{DISCUSSION}

\section{Factors Driving Farm Profitability}

Numerous factors contribute to the profitability of dairy farm systems. In temperate regions, grazed pasture is considered the cheapest feed available for dairy cows, and the suitability of Ireland's climate for forage production has given it a competitive advantage to produce high-quality milk from low-cost grazed pasture (Dillon et al., 2005; Finneran et al., 2012). There are also benefits to Ireland's pasture-based systems compared with the globally more common indoor TMR feeding system. Many studies have found pasturebased systems to be more sustainable (financially and environmentally), with grazing dairy cows converting non-human-edible protein into high-quality dairy products (Ferris, 2007; Acosta-Alba et al., 2012; O'Brien et al., 2014). There are also benefits based on consumer perceptions of the dairy industry that grazing systems are more sustainable, have higher animal welfare, and produce higher quality dairy products (Dillon et al., 2005; Peyraud et al., 2010). Therefore, to improve the efficiency of pasture-based systems, the utilization and production of grazed pasture should be maximized, whereas variable costs such as concentrate feed should be minimized to increase farm profitability (Macdonald et al., 2017; Hanrahan et al., 2018). Individual animal productivity is also a contributor that is influenced by environment, management, and genetic potential (Kearney et al., 2004; Hanrahan et al., 2018). Ultimately, whole-farm profitability relies mainly on pasture utilization, milk production per cow, stocking rate, and levels of supplementation (Hanrahan et al., 2018). This study highlights the effect sward type and cow genotype can have on farm profitability within an already efficient spring-calving, pasture-based production system.

\section{Influence of Sward Type on Farm Profitability}

Previous studies have shown that pasture utilization has huge potential for improvement in Ireland (Creighton et al., 2011; Kelly et al., 2013), which is an important factor for profitability when land area is limited. The use of legume forages, and white clover in particular, in PRG swards has the potential to reduce the consumption of artificial $\mathrm{N}$, reduce the carbon footprint of dairy systems, and increase pasture DM production and utilization and the nutritional value of forage (Lüscher et al., 2014; O'Brien et al., 2014; McClearn et al., 2019). Multiple studies confirm the biological results of the current study that clearly show the benefits of white clover inclusion in PRG swards in terms of herbage nutritive value (Beever et al., 1985; Søegaard, 1993; Enriquez-Hidalgo et al., 2018), pasture DM production (Enriquez-Hidalgo et al., 2016; Rodri- 
guez, 2016), and milk production from grazing animals (Woodward et al., 2001; Cosgrove et al., 2006; Egan et al., 2018). The significant increase in pasture production and utilization for PRG-white clover swards at the same $\mathrm{N}$ application rate as PRG-only swards $(+1,080 \mathrm{~kg}$ of $\mathrm{DM} / \mathrm{ha}$; Table 4) from the current study is in agreement with Egan at al. (2018), who compared PRG-white clover and PRG-only swards receiving 250 $\mathrm{kg}$ of $\mathrm{N}$ each and showed that the PRG-white clover sward produced $887 \mathrm{~kg}$ DM more herbage and that cows grazing the PRG-white clover swards produced an additional $33 \mathrm{~kg}$ of MSo/cow per year. The greater profitability of the PRG-white clover swards compared with PRG-only swards in this study (+€305/ha) was a result of the greater pasture utilization and MSo production per cow where sward white clover content was $23 \%$ on average. The additional costs of managing PRG-white clover swards compared with PRG-only swards in this study, such as feeding more silage in spring and the higher labor requirement for housing and feeding this silage, along with the extra grazing management required for paddocks with high white clover content (i.e., bloat oil inclusion in drinking water and extra fencing) for bloat management were included in this analysis. In previous studies, costs were typically lower with PRG-white clover swards due to reduced $\mathrm{N}$ fertilizer application (Schils et al., 2000; Humphreys et al., 2012) to encourage biological $\mathrm{N}$ fixing and increase the competitiveness of white clover (Brock, 2006; Dineen et al., 2018). Humphreys et al. (2012) compared PRG swards with high N input and PRG-white clover swards with lower $\mathrm{N}$ input and found the PRG swards to be more profitable due to higher output in milk sales combined with a higher stocking rate on PRG swards compared with PRG-white clover swards. Similarly, Schils et al. (2000) found a $10 \%$ lower gross margin per hectare (but higher gross margin per cow) for PRGwhite clover swards compared with PRG-only swards. However, both of these studies had lower $\mathrm{N}$ application rates for $\mathrm{PRG}$-white clover swards compared with PRG-only swards and so are not directly comparable with the current study.

\section{Reseeding Frequency and White Clover Persistence}

Due to the reduction of white clover in the sward over the 4-yr study period (reducing from $37 \%$ in yr 1 to $14 \%$ in yr 4; Guy et al., 2018; McClearn et al., 2019), an increased reseeding frequency to maintain sward white clover content was modeled to observe the effects on farm profitability. Reseeding of PRG-only swards typically occurs after a 10-yr period in higher performing grassland farms in Ireland (O'Donovan et al., 2017). The persistency of PRG within the sward is a key consideration and is now included in the pasture profit index (O'Donovan et al., 2017). Although reseeding every 5 yr versus $10 \mathrm{yr}$ significantly increased costs $(+€ 181 /$ ha $)$, net profit was still greater for PRG-white clover swards (+€252/ha) than for PRG-only swards, thereby making the additional effort and investment financially worthwhile. Shalloo et al. (2011) completed an economic analysis based on reseeding rates and found increased farm profitability from higher annual reseeding rates, associated with increased pasture utilization and stocking rate. Creighton et al. (2011) also found that higher stocked dairy farms had higher reseeding rates. The PRG-white clover swards in this study (McClearn et al., 2019) had significantly higher pasture production and utilization compared with PRG-only swards $(+1,205$ and $+1,080 \mathrm{~kg}$ of DM/ha, respectively). However, this additional herbage was produced in the summer months and mainly conserved as silage and subsequently was fed when there was an herbage deficit in spring due to lower overwinter growth on PRG-white clover swards (Guy, 2018; McClearn et al., 2019).

\section{Influence of Cow Genotype on Farm Profitability}

Previous studies have clearly illustrated the effect of cow genotype and genetic potential for milk production on farm profitability (Shalloo et al., 2004c; McCarthy et al., 2007; Ramsbottom et al., 2012). McCarthy et al. (2007) found that for pasture-based systems the most profitable cow type is one that has been selected for both production and fertility traits compared with those selected purely for production, highlighting the requirement for good reproductive performance in pasture-based systems. Poor reproductive performance negatively affects profitability through reduced milk yields and increased culling and replacement costs, which is exacerbated in spring-calving systems (Shalloo et al., 2014). The improvements in reproductive performance from crossbred animals compared with traditional HF cows have been well documented (Prendiville et al., 2011a; Vance et al., 2013; Ferris et al., 2014). Prendiville et al. (2011b) found JEX cows to be €184 more profitable/cow per lactation than HF cows due to better reproductive performance and the production of higher-value milk. However, in our study there were no differences between the 3 genotypes for reproductive traits. The reproductive performance of the HF cows in this study matched both of the crossbreds for key performance indicators such as 6- and 12-wk pregnancy rates, which is in contrast to previous research. The results of the current study show that within the economic 
scenarios modeled on an Irish pasture-based system, JEX cows were most profitable in every scenario (whole farm, per hectare, and per cow) compared with HF and 3 -way cows. These results were achieved through the higher milk price paid for milk with higher fat and protein content that is evident in crossbred herds (Coffey et al., 2018) and the increased stocking rates possible with JEX and 3-way cows (Coffey et al., 2018) and were achieved despite the lack of an effect of genotype on reproductive performance. The higher stocking rate possible for crossbred animals is based on their lower $\mathrm{BW}$ resulting in lower maintenance requirements and has been previously illustrated (Baudracco et al., 2010; Coffey et al., 2018). Additionally, the higher value of milk from crossbred animals similar to those used in this study has been reported before, in particular for Jersey crossbreds due to their higher milk fat and protein content compared with HF cows (Heins et al., 2008; Prendiville et al., 2011a; Coffey et al., 2016) and also for Norwegian Red crossbred animals (Heins et al., 2006; Walsh et al., 2008; Ferris et al., 2014). Although the difference in net profit per cow in this study is less than the €184 reported by Prendiville et al. (2011b), there is still benefit to crossbreeding within pasturebased production systems, both economically and in terms of milk production efficiency (McClearn et al., 2020). The EBI reflects the relative contributions of the different traits to overall profitability. When HF, JEX, and 3-way cows are compared in terms of EBI and economic performance, both crossbred cows (JEX and 3-way) had higher EBI compared with HF (€131 and $€ 159$ vs. €115; Table 1) and were more profitable on a per-cow basis. Ramsbottom et al. (2012) examined the relationship between herd EBI and farm profitability and concluded that herds with higher genetic merit for overall profitability were more profitable, with a €1.94/ cow change in net margin for every 1-unit change in EBI.

\section{Value of the Bull Calf}

The inclusion of differing calf prices for each genotype was taken into consideration for this comparison because the low value of Jersey bull calves is often of interest to farmers when making breeding decisions. Large retailers, conscious of the attitudes and opinions of their consumers, are encouraging their farmer suppliers to improve animal welfare, with calf mortality and age at slaughter being areas of concern (Mee, 2013). In Ireland, the predominant breed for dairy herds is HF, and bull calves are usually sold to be fattened for beef production or exported live. However, the use of Jersey bulls in breeding strategies has caused an issue with selling bull calves due to their smaller size and poor capacity for meat production, which accumulates into a negative perception for beef-finishing farmers (Nielsen and Thamsborg, 2002; Berry et al., 2018). In a beeffinishing study, when JEX bull calves were compared with HF bull calves, carcass weight was reduced by $12 \%$ and a poorer carcass conformation was observed (McNamee et al., 2015). However, McNamee et al. (2015) also found that Norwegian Red $\times$ HF bull calves had a similar beef production potential to HF bull calves, with superior carcass conformation at slaughter. The base assumption in the model was €53, €34, and €20 for the HF, 3-way, and JEX bull calves, respectively, which was based on actual market values from the 4-yr study (2014-2017). As part of the sensitivity analysis, the calf price difference was increased by $€ 30$ or $€ 60$ for both HF and 3-way calves compared with JEX calves to reflect the lower demand for JEX bull calves. This resulted in a lower profitability per cow for JEX (€882) compared with HF cows (€891); however, this was not reflected on a per-farm or per-hectare basis because JEX cows can be stocked higher than HF cows due to their lower BW and energy requirement. Therefore, when land area is the limiting factor, both crossbred cows were more profitable than HF cows regardless of calf value. This illustrates the low effect that calf value has on the profitability of dairy farms because the main source of income is from milk sales (Lopez-Villalobos et al., 2000).

\section{CONCLUSIONS}

The results of this MDSM simulation reveal a higher dairy production profitability when white clover is included in PRG-only swards, even when the higher costs incurred through white clover management are fully taken into consideration. The simulation also showed JEX cows to be the most profitable cow genotype when land area or cow numbers are limited, regardless of milk price or bull calf value. Therefore, the system that had the highest profitability in this simulation was JEX cows grazing PRG-white clover swards.

\section{ACKNOWLEDGMENTS}

This research was funded by the Irish Dairy Levy administered by Dairy Research Ireland (Dublin, Ireland). The first author received a Teagasc Walsh Fellowship. The authors gratefully acknowledge the invaluable assistance of the farm and technical staff based at Teagasc Clonakilty and Teagasc Moorepark (both in Co. Cork, Ireland). The authors have not stated any conflicts of interest. 


\section{REFERENCES}

Acosta-Alba, I., S. Lopéz-Ridaura, H. M. van der Werf, P. Leterme, and M. S. Corson. 2012. Exploring sustainable farming scenarios at a regional scale: An application to dairy farms in Brittany. J. Clean. Prod. 28:160-167. https://doi.org/10.1016/j.jclepro.2011 .11 .061 .

Baudracco, J., N. Lopez-Villalobos, C. Holmes, and K. Macdonald. 2010. Effects of stocking rate, supplementation, genotype and their interactions on grazing dairy systems: A review. N. Z. J. Agric. Res. 53:109-133. https://doi.org/10.1080/00288231003777665.

Beever, D. E., D. Thomson, M. Ulyatt, S. Cammell, and M. Spooner. 1985. The digestion of fresh perennial ryegrass (Lolium perenne L. cv. Melle) and white clover (Trifolium repens L. cv. Blanca) by growing cattle fed indoors. Br. J. Nutr. 54:763-775. https://doi .org/10.1079/bjn19850162.

Berry, D. P., M. Judge, R. Evans, F. Buckley, and A. Cromie. 2018. Carcass characteristics of cattle differing in Jersey proportion. J. Dairy Sci. 101:11052-11060. https://doi.org/10.3168/jds.2018 $-14992$.

Brock, J. 2006. Grazing management of white clover in mixed pastures. Proc. N. Z. Grassl. Assoc. 68:303-307.

Buckley, F., N. Lopez-Villalobos, and B. Heins. 2014. Crossbreeding: Implications for dairy cow fertility and survival. Animal 8(Suppl. 1):122-133. https://doi.org/10.1017/S1751731114000901.

Coffey, E. L., L. Delaby, C. Fleming, K. Pierce, and B. Horan. 2018. Multi-year evaluation of stocking rate and animal genotype on milk production per hectare within intensive pasture-based production systems. J. Dairy Sci. 101:2448-2462. https://doi.org/10 $.3168 /$ jds.2017-13632.

Coffey, E. L., L. Delaby, S. Fitzgerald, N. Galvin, K. M. Pierce, and B. Horan. 2017. Effect of stocking rate and animal genotype on dry matter intake, milk production, body weight, and body condition score in spring-calving, grass-fed dairy cows. J. Dairy Sci. 100:7556-7568. https://doi.org/10.3168/jds.2017-12672.

Coffey, E. L., B. Horan, R. D. Evans, and D. P. Berry. 2016. Milk production and fertility performance of Holstein, Friesian, and Jersey purebred cows and their respective crosses in seasonal-calving commercial farms. J. Dairy Sci. 99:5681-5689. https://doi.org/10 .3168/jds.2015-10530.

Cosgrove, G., J. Burke, A. Death, G. Lane, K. Fraser, and D. Pacheco. 2006. The effect of clover-rich diets on cows in mid lactation: Production, behaviour and nutrient use. Proc. N. Z. Grassl. Assoc. 68:267-273.

Creighton, P., E. Kennedy, L. Shalloo, T. Boland, and M. O'Donovan. 2011. A survey analysis of grassland dairy farming in Ireland, investigating grassland management, technology adoption and sward renewal. Grass Forage Sci. 66:251-264. https://doi.org/10.1111/j .1365-2494.2011.00784.x.

Delaby, L., E. Comeron, B. McCarthy, J. Pavie, and J. Peyraud. 2016. Les légumineuses fourragères, indispensables à l'élevage de demain. Fourrages (Versailles) 226:77-86.

Dillon, P., J. Roche, L. Shalloo, and B. Horan. 2005. Optimising financial return from grazing in temperate pastures. Pages 131-147 in Proc. Satellite Workshop of the XXth Int. Grassl. Congr. J. J. Murphy, ed. Wageningen Academic Publishers, Wageningen, the Netherlands.

Dineen, M., L. Delaby, T. Gilliland, and B. McCarthy. 2018. Metaanalysis of the effect of white clover inclusion in perennial ryegrass swards on milk production. J. Dairy Sci. 101:1804-1816. https:// doi.org/10.3168/jds.2017-12586.

Egan, M., N. Galvin, and D. Hennessy. 2018. Incorporating white clover (Trifolium repens L.) into perennial ryegrass (Lolium perenne L.) swards receiving varying levels of nitrogen fertilizer: Effects on milk and herbage production. J. Dairy Sci. 101:3412-3427. https:/ /doi.org/10.3168/jds.2017-13233.

Enriquez-Hidalgo, D., T. Gilliland, M. Deighton, M. O'Donovan, and D. Hennessy. 2014. Milk production and enteric methane emissions by dairy cows grazing fertilized perennial ryegrass pasture with or without inclusion of white clover. J. Dairy Sci. 97:1400-1412. https://doi.org/10.3168/jds.2013-7034.
Enriquez-Hidalgo, D., T. Gilliland, M. Egan, and D. Hennessy. 2018. Production and quality benefits of white clover inclusion into ryegrass swards at different nitrogen fertilizer rates. J. Agric. Sci. 156:378-386. https://doi.org/10.1017/S0021859618000370.

Enriquez-Hidalgo, D., T. Gilliland, and D. Hennessy. 2016. Herbage and nitrogen yields, fixation and transfer by white clover to companion grasses in grazed swards under different rates of nitrogen fertilization. Grass Forage Sci. 71:559-574. https://doi.org/10 $.1111 /$ gfs. 12201.

Ferris, C. 2007. Sustainable pasture based dairy systems-Meeting the challenges. Can. J. Plant Sci. 87:723-738. https://doi.org/10 .4141/CJPS06011.

Ferris, C. P., D. Patterson, F. Gordon, S. Watson, and D. Kilpatrick. 2014. Calving traits, milk production, body condition, fertility, and survival of Holstein-Friesian and Norwegian Red dairy cattle on commercial dairy farms over 5 lactations. J. Dairy Sci. 97:52065218. https://doi.org/10.3168/jds.2013-7457.

Finneran, E., P. Crosson, P. O'Kiely, L. Shalloo, D. Forristal, and M. Wallace. 2012. Stochastic simulation of the cost of home-produced feeds for ruminant livestock systems. J. Agric. Sci. 150:123-139. https://doi.org/10.1017/S002185961100061X.

Geary, U., N. Lopez-Villalobos, D. Garrick, and L. Shalloo. 2010. Development and application of a processing model for the Irish dairy industry. J. Dairy Sci. 93:5091-5100. https://doi.org/10.3168/jds .2010-3487.

Guy, C. 2018. Impact of Lolium perenne L. ploidy and Trifolium repens L. inclusion on sward structural characteristics, morphology and nutritive value in grazing swards. PhD Diss. Queen's University Belfast, Belfast, Northern Ireland.

Guy, C., D. Hennessy, T. J. Gilliland, F. Coughlan, B. McClearn, M. Dineen, and B. McCarthy. 2018. Comparison of perennial ryegrass, Lolium perenne L., ploidy and white clover, Trifolium repens L., inclusion for herbage production, utilization and nutritive value. Grass Forage Sci. 73:865-877. https://doi.org/10.1111/gfs.12366.

Hanrahan, L., N. McHugh, T. Hennessy, B. Moran, R. Kearney, M. Wallace, and L. Shalloo. 2018. Factors associated with profitability in pasture-based systems of milk production. J. Dairy Sci. 101:5474-5485. https://doi.org/10.3168/jds.2017-13223.

Heins, B. J., L. Hansen, and A. Seykora. 2006. Production of pure Holsteins versus crossbreds of Holstein with Normande, Montbeliarde, and Scandinavian Red. J. Dairy Sci. 89:2799-2804. https:/ /doi.org/10.3168/jds.S0022-0302(06)72356-6.

Heins, B. J., L. Hansen, A. Seykora, D. Johnson, J. Linn, J. Romano, and A. Hazel. 2008. Crossbreds of Jersey $\times$ Holstein compared with pure Holsteins for production, fertility, and body and udder measurements during first lactation. J. Dairy Sci. 91:1270-1278. https://doi.org/10.3168/jds.2007-0564.

Humphreys, J., E. Mihailescu, and I. Casey. 2012. An economic comparison of systems of dairy production based on $\mathrm{N}$-fertilized grass and grass-white clover grassland in a moist maritime environment. Grass Forage Sci. 67:519-525. https://doi.org/10.1111/j.1365-2494 .2012.00871.x.

Jarrige, R. 1989. Ruminant Nutrition: Recommended Allowances and Feed Tables. John Libbey Eurotext, Paris, France.

Kearney, J. F., M. Schutz, P. Boettcher, and K. Weigel. 2004. Genotype $\times$ environment interaction for grazing versus confinement. I. Production traits. J. Dairy Sci. 87:501-509. https://doi.org/10 .3168/jds.S0022-0302(04)73189-6.

Kelly, E., L. Shalloo, U. Geary, A. Kinsella, F. Thorne, and M. Wallace. 2013. An analysis of the factors associated with technical and scale efficiency of Irish dairy farms. Int. J. Agric. Manage. 2:149-159. https://doi.org/10.5836/ijam/2013-03-04.

Läpple, D., T. Hennessy, and M. O'Donovan. 2012. Extended grazing: A detailed analysis of Irish dairy farms. J. Dairy Sci. 95:188-195. https://doi.org/10.3168/jds.2011-4512.

Läpple, D., and G. Sirr. 2019. Dairy intensification and quota abolition: A comparative study of production in Ireland and the Netherlands. EuroChoices (Uckfield) 18:26-32. https://doi.org/10 $.1111 / 1746-692 X .12213$.

Lopez-Villalobos, N., D. J. Garrick, C. W. Holmes, H. T. Blair, and R. J. Spelman. 2000. Profitabilities of some mating systems for dairy 
herds in New Zealand. J. Dairy Sci. 83:144-153. https://doi.org/ 10.3168/jds.S0022-0302(00)74865-X.

Lüscher, A., I. Mueller-Harvey, J.-F. Soussana, R. Rees, and J.-L. Peyraud. 2014. Potential of legume-based grassland-livestock systems in Europe: A review. Grass Forage Sci. 69:206-228. https://doi .org $/ 10.1111 / \mathrm{gfs} .12124$.

Macdonald, K. A., J. Penno, J. Lancaster, A. Bryant, J. Kidd, and J. Roche. 2017. Production and economic responses to intensification of pasture-based dairy production systems. J. Dairy Sci. 100:66026619. https://doi.org/10.3168/jds.2016-12497.

Macdonald, K. A., J. Penno, J. Lancaster, and J. Roche. 2008. Effect of stocking rate on pasture production, milk production, and reproduction of dairy cows in pasture-based systems. J. Dairy Sci. 91:2151-2163. https://doi.org/10.3168/jds.2007-0630.

McCarthy, S., B. Horan, P. Dillon, P. O'Connor, M. Rath, and L. Shalloo. 2007. Economic comparison of divergent strains of Holstein-Friesian cows in various pasture-based production systems. J. Dairy Sci. 90:1493-1505. https://doi.org/10.3168/jds.S0022 -0302(07) 71635-1.

McClearn, B., L. Delaby, T. J. Gilliland, C. Guy, M. Dineen, F. Coughlan, F. Buckley, and B. McCarthy. 2020. An assessment of the production, reproduction and functional traits of HolsteinFriesian, Jersey $\times$ Holstein-Friesian and Norwegian Red $\times($ Jersey $\times$ Holstein-Friesian) cows in pasture-based systems. J. Dairy Sci. https://doi.org/10.3168/jds.2019-17476.

McClearn, B., T. Gilliland, L. Delaby, C. Guy, M. Dineen, F. Coughlan, and B. McCarthy. 2019. Milk production per cow and per hectare of spring-calving dairy cows grazing swards differing in Lolium perenne L. ploidy and Trifolium repens L. composition. J. Dairy Sci. 102:8571-8585. https://doi.org/10.3168/jds.2018-16184.

McGilloway, D. A. 2005. Grassland: A Global Resource. Wageningen Academic Publishers, Wageningen, the Netherlands.

McNamee, A., M. Keane, D. Kenny, A. Moloney, F. Buckley, and E. O'Riordan. 2015. Beef production from Holstein-Friesian, Norwegian Red $\times$ Holstein-Friesian and Jersey $\times$ Holstein-Friesian male cattle reared as bulls or steers. Livest. Sci. 173:95-105. https://doi .org/10.1016/j.livsci.2014.12.009.

Mee, J. F. 2013. Why do so many calves die on modern dairy farms and what can we do about calf welfare in the future? Animals (Basel) 3:1036-1057. https://doi.org/10.3390/ani3041036.

Nielsen, B., and S. M. Thamsborg. 2002. Dairy bull calves as a resource for organic beef production: A farm survey in Denmark. Livest. Prod. Sci. 75:245-255. https://doi.org/10.1016/S0301 -6226(01)00322-0.

O'Brien, D., J. Capper, P. Garnsworthy, C. Grainger, and L. Shalloo. 2014. A case study of the carbon footprint of milk from highperforming confinement and grass-based dairy farms. J. Dairy Sci. 97:1835-1851. https://doi.org/10.3168/jds.2013-7174.

O'Donovan, M., N. McHugh, M. McEvoy, D. Grogan, and L. Shalloo. 2017. Combining seasonal yield, silage dry matter yield, quality and persistency in an economic index to assist perennial ryegrass variety selection. J. Agric. Sci. 155:556-568. https://doi.org/10 .1017/S0021859616000587.

Peyraud, J., A. van den Pol, P. Dillon, and L. Delaby. 2010. Producing milk from grazing to reconcile economic and environmental performances. Pages 163-164 in Proc. 23rd General Meeting of the European Grassland Federation, Kiel, Germany. European Grassland Federation, Zurich, Switzerland.

Prendiville, R., K. Pierce, L. Delaby, and F. Buckley. 2011a. Animal performance and production efficiencies of Holstein-Friesian, Jersey and Jersey $\times$ Holstein-Friesian cows throughout lactation. Livest. Sci. 138:25-33. https://doi.org/10.1016/j.livsci.2010.11.023.

Prendiville, R., L. Shalloo, K. Pierce, and F. Buckley. 2011b. Comparative performance and economic appraisal of Holstein-Friesian, Jersey and Jersey $\times$ Holstein-Friesian cows under seasonal pasture-based management. Ir. J. Agric. Food Res. 50:123-140.

Ramsbottom, G., A. Cromie, B. Horan, and D. P. Berry. 2012. Relationship between dairy cow genetic merit and profit on commercial spring calving dairy farms. Animal 6:1031-1039. https://doi.org/ 10.1017/S1751731111002503.

Ramsbottom, G., B. Horan, D. P. Berry, and J. Roche. 2015. Factors associated with the financial performance of spring-calving, pasture-based dairy farms. J. Dairy Sci. 98:3526-3540. https://doi .org $/ 10.3168 / \mathrm{jds} .2014-8516$.

Rodriguez, L. R. 2016. Interactions between pasture species and management and their implications for evaluating perennial ryegrass (Lolium perenne L.) cultivars in dairy systems. PhD Diss. Lincoln University, Lincoln, Canterbury, New Zealand.

Schils, R., T. Boxem, C. Jagtenberg, and M. Verboon. 2000. The performance of a white clover based dairy system in comparison with a grass/fertiliser-N system. II. Animal production, economics and environment. Wagening. J. Life Sci. 48:305-318. https://doi.org/ 10.1016/S1573-5214(00)80020-2.

Shalloo, L., P. Creighton, and M. O'Donovan. 2011. The economics of reseeding on a dairy farm. J. Agric. Food Res. 50:113-122.

Shalloo, L., A. Cromie, and N. McHugh. 2014. Effect of fertility on the economics of pasture-based dairy systems. Animal 8(Suppl. 1):222-231. https://doi.org/10.1017/S1751731114000615.

Shalloo, L., P. Dillon, J. O'Loughlin, M. Rath, and M. Wallace. 2004a. Comparison of a pasture-based system of milk production on a high rainfall, heavy-clay soil with that on a lower rainfall, freedraining soil. Grass Forage Sci. 59:157-168. https://doi.org/10 .1111/j.1365-2494.2004.00415.x.

Shalloo, L., P. Dillon, M. Rath, and M. Wallace. 2004b. Description and validation of the Moorepark dairy system model. J. Dairy Sci. 87:1945-1959. https://doi.org/10.3168/jds.S0022-0302(04)73353 $-6$.

Shalloo, L., J. Kennedy, M. Wallace, M. Rath, and P. Dillon. 2004c. The economic impact of cow genetic potential for milk production and concentrate supplementation level on the profitability of pasture based systems under different EU milk quota scenarios. J. Agric. Sci. 142:357-369. https://doi.org/10.1017/S002185960400437X.

Søegaard, K. 1993. Nutritive value of white clover. Pages 17-23 in White Clover in Europe: State of the Art. REUR Technical Series 29. Food and Agriculture Organization of the United Nations, Rome, Italy.

Teagasc. 2013. Management Data for Farm Planning. Teagasc, Oakpark, Co. Carlow, Ireland.

Vance, E., C. Ferris, C. Elliott, H. Hartley, and D. Kilpatrick. 2013. Comparison of the performance of Holstein-Friesian and Jersey $\times$ Holstein-Friesian crossbred dairy cows within three contrasting grassland-based systems of milk production. Livest. Sci. 151:66-79. https://doi.org/10.1016/j.livsci.2012.10.011.

Walsh, S., F. Buckley, D. Berry, M. Rath, K. Pierce, N. Byrne, and P. Dillon. 2007. Effects of breed, feeding system, and parity on udder health and milking characteristics. J. Dairy Sci. 90:5767-5779. https://doi.org/10.3168/jds.2007-0389.

Walsh, S., F. Buckley, K. Pierce, N. Byrne, J. Patton, and P. Dillon. 2008. Effects of breed and feeding system on milk production, body weight, body condition score, reproductive performance, and postpartum ovarian function. J. Dairy Sci. 91:4401-4413. https:// doi.org/10.3168/jds.2007-0818.

Woodward, S., K. MacDonald, W. Carter, J. Eerens, and J. Crush. 2001. Milksolids production from different combinations of perennial ryegrass and white clover cultivars: II Milksolids production and farm profitability. Proc. N. Z. Grassl. Assoc. 63:97-102.

\section{ORCIDS}

B. McClearn () https://orcid.org/0000-0002-6370-705X

L. Shalloo ( https://orcid.org/0000-0003-1714-672X

T. J. Gilliland ๑ https://orcid.org/0000-0002-4514-1435 